\title{
Effects of p-chlorophenylalanine on conditioned avoidance learning'
}

KURT SCHLESINGER, ROBERT A. SCHREIBER, DEPARTMENT OF PSYCHOLOGY AND THE INSTITUTE FOR BEHAVIORAL GENETICS, UNIVERSITY OF COLORADO, Denver, Colo., AND GORDON T. PRYOR, LIFE SCIENCES RESEARCH, STANFORD RESEARCH INSTITUTE, Menlo Park, Calif. 94025

$A$ single injection of p-chlorophenylalanine enhanced the performance of two strains of rats in a conditioned avoidance task. The enhancement was especially evident at low UCS intensities for one strain and at high UCS intensities for the other strain. Chronic p-chlorophenylalanine treatment retarded the performance of rats and mice in conditioned avoidance tasks.

$\mathrm{p}-\mathrm{Chlorophenylalanine} \mathrm{(} \mathrm{p}-\mathrm{ChPhe}$ ) inhibits the tryptophan- and phenylalanine-hydroxylating capabilities of liver tissue (Koe \& Weissman, 1966). It also depletes 5-hydroxytryptamine (5-HT) levels in brain without appreciably affecting levels of norepinephrine. Three days after a single injection of $\mathrm{p}-\mathrm{ChPhe}(316 \mathrm{mg} / \mathrm{k} \mathrm{g})$, levels of $5-\mathrm{HT}$ in brain are reduced to less than $10 \%$ of normal; however, no gross behavioral effects are noted (Koe \& Weissman, 1966). This drug also increases plasma phenylalanine levels and thus mimics the human disease phenylketonuria; if $p$-ChPhe treatment is combined with the administration of phenylalanine, large increases in levels of this amino acid are observed but levels of tyrosine are increased only slightly (Lipton et al, 1967).

The effects of $\mathrm{p}$-ChPhe on several behaviors have recently been investigated. Tenen (1967) reported that this drug increased the rate of acquisition of an active conditioned avoidance response when low UCS intensities $(0.35 \mathrm{~mA})$ were used but not when high UCS intensities $(0.95 \mathrm{~mA})$ were used. He also reported that p-ChPhe increased pain sensitivity and reduced "emotional reactivity." For this reason and since p-ChPhe treatment had no effect on acquisition of a position habit in a T-maze using water reinforcement, Tenen (1967) concluded that the effects of this drug on the conditioned avoidance response were attributable to motivational variables. Stevens et al (1967), however, reported that although a position habit and its reversal were unaffected by $\mathrm{p}-\mathrm{ChPhe}$, both a simultaneous and successive brightness discrimination habit were acquired more rapidly following treatment with this drug.

The present experiments were performed to provide additional information on the effects of $p$-ChPhe on performance in conditioned avoidance tasks-specifically, the effects of (1) a single acute injection on conditioned avoidance learning as a function of UCS intensity in two strains of rats, and (2) chronic injections on conditioned avoidance learning in (a) one strain of rats and (b) two strains of mice.

Methods. For the first experiment 72 male rats of the Fisher and Buffalo strains were used. The origin and degree of inbreeding of these rats has been described (Jay, 1963). The animals were 50 days old at the beginning of the experiment. Half of the animals within each strain served as controls and received oral injections of $10 \mathrm{ml} / \mathrm{kg}$ of vehicle $(0.5 \%$ tragacanth $)$; the other animals received $320 \mathrm{mg} / \mathrm{kg}$ of $\mathrm{p}-\mathrm{ChPhe}$ suspended in tragacanth. All injections were given three days before the conditioned avoidance test. The animals were further subdivided into three groups, receiving either $0.25,0.5$, or $1.0 \mathrm{~mA}$ footshock as the UCS.

For the second experiment 28 male and female rats of the Fisher strain were used. Controls (13 rats) were given oral injections of vehicle $(0.5 \%$ tragacanth). The 15 experimental Ss were given $\mathrm{p}-\mathrm{ChPhe}(320 \mathrm{mg} / \mathrm{kg})$ suspended in tragacanth. The injections were given $24 \mathrm{~h}$ after birth and every third day thereafter. All animals were tested for conditioned avoidance learning when 41 days of age. The UCS in this experiment was a $0.5 \mathrm{~mA}$ footshock for all animals.

For the third experiment 72 male and female mice of the DBA/2J and $\mathrm{C} 57 \mathrm{BL} / 6 \mathrm{~J}$ strain were used. The origin and degree of inbreeding of these mice has been described (Jay, 1963). Half of the animals of each strain served as controls and were given ip injections of distilled water $48 \mathrm{~h}$ after birth and every third day thereafter. The other animals served as experimental Ss and were similarly injected with $\mathrm{p}-\mathrm{ChPhe}(320 \mathrm{mg} / \mathrm{kg})$ suspended in distilled water. All mice were tested for conditioned avoidance learning when 21 days of age.

Avoidance training in rats was carried out in $12 \times 24 \times 24$ in. units with an 8 in. pole suspended from the ceiling. Pulling or climbing the pole constituted the avoidance response and terminated the trial. The CS was an easily

Table 1

Effects of Acute and Chronic p-Chlorophenylalanine Treatment on Conditioned Avoidance Learning in Rats

\begin{tabular}{|c|c|c|c|c|c|}
\hline \multirow[b]{2}{*}{ Genotype } & \multirow[b]{2}{*}{$\mathbf{N}$} & \multirow[b]{2}{*}{ Treatment } & \multirow{2}{*}{$\begin{array}{c}\text { UCS } \\
\text { Intensity }\end{array}$} & \multicolumn{2}{|c|}{$\overline{\mathrm{X}}$ Number of Responses \pm 1 S.D. } \\
\hline & & & & CARs & Total Responses ${ }^{1}$ \\
\hline \multicolumn{6}{|c|}{ Experiment 1 - Acute Treatment } \\
\hline Buffalo & 12 & Control & $0.25 \mathrm{~mA}$ & $2.8 \pm 5.0$ & $4.5 \pm 7.8$ \\
\hline Buffalo & 12 & Control & $0.50 \mathrm{~mA}$ & $5.0 \pm 4.2$ & $12.8 \pm 7.5$ \\
\hline Buffalo & 12 & Control & $1.00 \mathrm{~mA}$ & $4.2 \pm 3.8$ & $17.8 \pm 1.9$ \\
\hline Buffalo & 12 & p-ChPhe & $0.25 \mathrm{~mA}$ & $3.4 \pm 3.9$ & $9.0 \pm 8.6$ \\
\hline Buffalo & 12 & p-ChPhe & $0.50 \mathrm{~mA}$ & $6.4 \pm 5.5$ & $13.8 \pm 7.9$ \\
\hline Buffalo & 12 & p-ChPhe & $1.00 \mathrm{~mA}$ & $8.3 \pm 5.3$ & $15.9 \pm 5.2$ \\
\hline Fisher & 12 & Control & $0.25 \mathrm{~mA}$ & $6.0 \pm 3.7$ & $15.0 \pm 7.1$ \\
\hline Fisher & 12 & Control & $0.50 \mathrm{~mA}$ & $7.1 \pm 3.9$ & $15.7 \pm 7.44$ \\
\hline Fisher & 12 & Control & $1.00 \mathrm{~mA}$ & $8.5 \pm 4.4$ & $18.8 \pm 1.7$ \\
\hline Fisher & 12 & p-ChPhe & $0.25 \mathrm{~mA}$ & $10.4 \pm 2.7$ & $17.0 \pm 5.5$ \\
\hline Fisher & 12 & p-ChPhe & $0.50 \mathrm{~mA}$ & $10.7 \pm 3.6$ & $19.2 \pm 1.0$ \\
\hline Fisher & 12 & p-ChPhe & $1.00 \mathrm{~mA}$ & $10.7 \pm 3.0$ & $19.0 \pm 1.5$ \\
\hline \multicolumn{6}{|c|}{ Experiment 2 -Chronic Treatment } \\
\hline Fisher & 15 & Control & $0.5 \mathrm{~mA}$ & $4.27 \pm 3.98$ & $15.47 \pm 10.91$ \\
\hline Fisher & 13 & p-ChPhe & $0.5 \mathrm{~mA}$ & $1.92 \pm 7.16$ & $8.38 \pm 9.15$ \\
\hline
\end{tabular}

${ }^{1}$ All conditioned responses, i.e., CARs plus escape responses. 
Table 2

Effects of Chronic $\mathrm{p}$-Chlorophenylalanine Treatment on Conditioned Avoidance Learning and Extinction in Mice

$\overline{\mathrm{X}}$ Number of Trials to Criterion \pm 1 S.D.

\begin{tabular}{llccc} 
Genotype & $\mathrm{N}$ & Treatment & Acquisition & Extinction \\
\hline DBA/2J & 18 & Control & $13.0 \pm 1.4$ & $19.7 \pm 8.9$ \\
DBA/2J & 18 & p-ChPhe & $15.9 \pm 4.9$ & $22.4 \pm 11.7$ \\
C57BL/6J & 18 & Control & $14.9 \pm 5.6$ & $20.9 \pm 9.1$ \\
C57BL/6J & 18 & p-ChPhe & $18.5 \pm 5.6$ & $33.7 \pm 14.1$ \\
\hline
\end{tabular}

discriminable change in the intensity of the ambient light and sound. The CS preceded the UCS by $10 \mathrm{sec}$. The CS and UCS continued until a response was made or for a maximum of $45 \mathrm{sec}$. Twenty trials were given, with a random intertrial interval of 2 to $4 \mathrm{~min}$.

Avoidance training in mice was carried out in the apparatus and by the procedure described by Schlesinger \& Wimer (1967). Basically, the apparatus consisted of a plastic box with a grid floor and a plastic escape shelf. A $25 \mathrm{~W}$ light bulb and a buzzer mounted directly above the rear of the box served as the CS. Termination of the $3 \mathrm{sec}$ CS coincided with the onset of the UCS, a $0.2 \mathrm{~mA}$ footshock. The UCS was continued until the animal jumped to the escape shelf. Intertrial intervals were approximately $15 \mathrm{sec}$. Training was continued until the animals reached a criterion of eight out of 10 avoidance responses or for a total of 50 trials. Extinction training was begun immediately after acquisition. The procedure was identical to that for acquisition training except that the UCS was not turned on. Animals were extinguished to a criterion of eight failures to avoid in 10 trials or for a total of 50 extinction trials.

Results. Analysis of variance of the total number of avoidance responses in the first experiment (see Table 1) revealed that the strain and drug sources of variance were highly significant $(\mathrm{p}<$ $.001)$, as was the effect of UCS intensity $(p<.025)$. In general, Fisher rats were superior in performance to Buffalo rats, treated rats were superior to their controls, and performance improved with increasing UCS intensity. The drug $x$ strain and the drug $x$ strain $x$ UCS intensity interactions failed to reach acceptable levels of significance. However, separate $t$ tests indicated that the treated animals were superior to their respective controls only at 0.25 and $0.5 \mathrm{~mA}$ of UCS intensity for the Fisher rats $(\mathrm{p}<.05$ and $<.01)$, and at $1.0 \mathrm{~mA}$ for the Buffalo rats $(\mathrm{p}<.05)$. Inspection of these data showed that many of the Buffalo rats failed to make even a single conditioned response at the lower shock intensity; only three of the control and seven of the treated Buffalo rats responded at $0.25 \mathrm{~mA}$, compared with 10 and 11 Fisher rats. However, analysis of the data in terms of all conditioned responses, i.e., CARs plus escape responses, failed to differentiate control from treated rats at any UCS intensity for either strain.

Analysis of the data for control and chronically treated Fisher rats (Experiment 2, Table 1) failed to reveal significant differences between control and treated rats in number of CARs. However, in terms of total number of conditioned responses, treated animals did significantly poorer than controls $(t=2.64$, df $=26, p<$ $.01)$.

The effects of chronic administration of $\mathrm{p}-\mathrm{ChPhe}$ in mice are summarized in Table 2. Analyses of variance of the data, separately for the acquisition and extinction phases of the experiment, revealed significant strain $(p \leqslant .01)$ and drug $(p \leqslant .025)$ effects; the drug by strain interactions failed to reach acceptable levels of significance. Separate $t$ tests showed that treated mice required significantly more trials to reach the acquisition criterion than did controls $(\mathrm{C} 57 \mathrm{BL} / 6 \mathrm{~J}: \mathrm{t}=4.5, \mathrm{df}=34, \mathrm{p} \leqslant .001 ; \mathrm{DBA} / 2 \mathrm{~J}: \mathbf{t}=4.9$, $\mathrm{df}=34, \mathrm{p} \leqslant .001)$. Treated mice also required more trials to reach the extinction criterion than did controls $(\mathrm{C} 57 \mathrm{BL} / 6 \mathrm{~J}: \mathrm{t}=11.3, \mathrm{df}$ $=34, \mathrm{p} \leqslant .001 ; \mathrm{DBA} / 2 \mathrm{~J}: \mathrm{t}=2.5, \mathrm{df}=34, \mathrm{p} \leqslant .05$ ).

Discussion. These data show that performance in conditioned avoidance situations is enhanced by a single injection of $\mathrm{p}-\mathrm{ChPhe}$ but is retarded by chronic treatment. Tenen (1967) reported that acute $p-C h P h e$ treatment enhances performance in active avoidance situations, but only at low UCS intensities. Since this drug treatment also lowered pain sensitivity and increased emotional reactivity, Tenen (1967) concluded that the enhanced performance observed in $p$-ChPhe treated animals was due to motivational variables. Stevens et al (1967) reported that $\mathrm{p}-\mathrm{ChPhe}$ enhanced performance in an active avoidance task at low UCS intensities in Fisher rats, but at high UCS intensities in Buffalo rats. Thus, although it now appears clear that p-ChPhe does improve performance, it is not known whether this is due to the effects of this drug on motivational variables or whether $\mathrm{p}$-ChPhe facilitates the formation of associations. The mechanisms underlying these effects are also not fully understood; it seems reasonable, however, that the effects are due to low levels of 5-HT in brain since Wooley \& van der Hoeven (1963) found that mice learned a position habit as an inverse function of levels of 5-HT in brain.

Chronic administration of $\mathrm{p}$-ChPhe has adverse effects on performance in active avoidance situations. Since such treatment mimics human phenylketonuria, i.e., increases levels of phenylalanine and lowers levels of 5-HT, it seems plausible to attribute these results to mechanisms similar to those responsible for the mental retardation associated with phenylketonuria. It should be pointed out that in these experiments p-ChPhe treatment was begun very early, either 24 or $48 \mathrm{~h}$ after birth. Whether similar durations of treatment started later in development would have similar effects remains to be determined.

\section{REFERENCES}

JAY, G. E., Jr., Genetic strains and stocks. In W. J. Burdette (Ed.), Methodology in mammalian genetics. San Francisco: Holden-Day, 1963.

KOE, B. K., \& WEISSMAN, A. p-Chlorophenylalanine: A specific depletor of brain serotonin. J. Pharmacol. exp. Ther., 1966, 154, 499-516.

LIPTON, M. A., GORDON, R., GUROFF, G., \& UDENFRIEND, S. p-Chlorophenylalanine-induced chemical manifestations of phenylketonuria in rats. Science, 1967, 156, 248-250.

SCHLESINGER, K., \& WIMER, R. Genotype and conditioned avoidance learning in the mouse. J. comp. physiol Psychol., 1967, 63, 139-141.

STEVENS, D. A., RESNICK, O., \& KRUS, D. M. The effects of p-chlorophenylalanine, a depletor of brain serotonin, on behavior: I. Facilitation of discrimination learning. Life Sci, 1967, 6, 2215-2220.

TENEN, S. S. The effects of p-chlorophenylalanine, a serotonin depletor, on avoidance acquisition, pain sensitivity and related behavior in the rat. Psychopharmacologia, 1967, 10, 204-219.

WOOLEY, D. W., \& VAN DER HOEVEN, T. Alterations in learning ability caused by changes in cerebral serotonin and catechol amines. Science, $1963,139,610-611$.

\section{NOTE}

1. This research was supported in part by Research Grant MH-13026 from the National Institute for Mental Health to the senior author, and in part by Contract Nonr-2993(00) between the United States Office of Naval Research and Stanford Research Institute. p-Chlorophenylalanine was a gift received from Charles Pfizer and Co., Inc. 